\title{
Habitat Characteristics, Diversity, and Pattern of Distribution of Anopheles Sp Larvae in The Ogan Komering Ilir District, South Sumatra
}

\author{
Yuanita Windusari ${ }^{1}$, Nur Alam Fajar ${ }^{2}$, Dini Arista Putri ${ }^{3}$, Laila hanum ${ }^{4}$, Fitra Febriyanti ${ }^{5}$ \\ \{ ywindusari@yahoo.com ${ }^{1}$,mr.nuralamfajar@unsri.ac.id ${ }^{2}$, dini.aristaputri@unsri.ac.id ${ }^{3}$ \\ lailahanum@gmail.com ${ }^{4}$, Fitra Febriyanti@gmail.com ${ }^{5}$ \} \\ Department of Environmental Health, Faculty of Public Health, Sriwijaya University $1,2,3$ \\ Department of Biology, Faculty of Mathematics and Natural Science, Sriwijaya University, \\ Indonesia ${ }^{4,5}$
}

\begin{abstract}
Malaria is induced by a parasitic infection of Plasmodium that lives and multiplies in infected red blood cells. As vector of malaria, the presence of Anopheles sp is governed by biotic and abiotic environmental conditions. The research was carried out to determine the habitat characteristics and pre-adult distribution of Anopheles sp in Kemelak Bindung Langit Village, Ogan Komering Ulu District. The selected location was based on purposive sampling method and observational. The water temperature in the recorded habitat ranges between $28-31^{\circ} \mathrm{C}, \mathrm{pH}$ ranges from 5-6, and humidity is $60 \%-$ $70 \%$. The collected larvae were put into glasses to be tamed in laboratory. Identification was done after adult mosquitoes. The results show that the habitat favoured by Anopheles $\mathrm{sp}$ was waters that were overgrown with water plants. In natural habitats, the development of larvae is limited by the presence of predators such as water fleas, dragonfly larvae, tadpoles, and fish, and is affected by the flow of water. The morisita index analysis shows the distribution pattern of Anopheles $\mathrm{sp}$ at the sampling location is uniform. It was concluded that the habitat in the Bindung Langit Village, Ogan Komering Ulu District, South Sumatra had characteristics suitable for the breeding of Anopheles sp larvae. Temperature and humidity in the region create comfortable conditions for larvae and potentially increase the Anopheles sp population.
\end{abstract}

Keywords: Anopheles sp, malaria, endemic, parasite infection, habitat

\section{Introduction}

One of the public health problems in developing countries is the high level of vector-borne diseases such as malaria. Anopheles spare insects that spread malaria vectors. Female mosquitoes infected with Plasmodium parasites can transmit this disease. The distribution of this disease is still relatively high in the world. The results of research conducted by [1] show that> 500 million of the world's population are affected by clinical symptoms of malaria, and 1 million people die each year from malaria. In Indonesia, Anopheles sp are widely distributed in various regions and characteristics and differences in lifestyle of typical local communities. This condition causes changes in life characteristics and adaptation of Anopheles sp in an area.

Eight of the 13 districts in South Sumatra are declared endemic malaria areas. Data from the South Sumatra Provincial Health Office states that 8 out of 1000 people in South Sumatra 
are at risk of being infected. In 2012, the value of the Annual Parasite Incident (API) of South Sumatra Province was 0.62 per 1000 population. One of the endemic malaria districts is Ogan Komering Ulu District with an API score of 0.44 per 1,000 population (South Sumatra Provincial Health Office, 2012 in [2]. In 2014, Ogan Komering Ulu District had the highest number of positive malaria cases in South Sumatra with an API value of 1.50 per 1000 population [3].

According to [2], geographical location and physical, chemical and biological environmental conditions such as habitat type, temperature, $\mathrm{pH}$, the turbidity of the waters, sunlight, water flow, rainfall, wind, the presence of vegetation and the presence of predators are very good supporting factors for the life cycle of Anopheles sp. The development of Anopheles larvae and adult mosquito populations live comfortably in tropical climates with warm temperatures and high humidity.

Malaria transmission occurs due to agent interactions (Plasmodium), definitive host (Anopheles sp) and intermediate host (human). Malaria transmission is influenced by the presence and fluctuations of Anopheles $s p$ vector or mosquito population spp. Rainfall intensity, source of Plasmodium. Or the presence of sufferers and vulnerable hosts also accelerate the spread of this disease. Source of Plasmodium parasites is the host who became malaria positive. In endemic areas, there are often no clinical symptoms in the patient even though the parasite stays alive in the patient's body. This is due to changes in the level of human resistance to malaria parasites due to the frequency of contact with parasites. In some countries, parasite immunity is found due to genetic mutations [4].

Based on the statements that have been stated, a study was conducted to find out and study habitat characteristics and distribution of Anopheles $\mathrm{sp}$ in Ogan Komering Ulu district, especially in the village of Kemelak Bindung Langit which has a high incidence of malaria in the district. The information obtained will be used as a scientific information source to prevent wider vector distribution.

\section{Material and Method}

Anopheles larvae are taken from a variety of natural habitats such as rice fields, duck ponds, puddles of used vehicle tires, and swamps found in the village of Kemelak Bindung Langit, Ogan Komering Ulu District, South Sumatra. The study was conducted during December 2017-March 2018.

This type of research is observationally based on purposive sampling technique. Environmental factors observed were $\mathrm{pH}$, water and air temperature, light intensity, habitat distance interval with settlements, water vegetation, and types of predators found. Morisita index is used to identify the distribution of Anopheles sp and make nursery maps.

Purposive sampling technique is used as a basis for determining the sampling location. Sampling is done at places that are thought to be the breeding ground for mosquito larvae. A total of 10 times water taken to the representation of samples, domestication, and identification. Mosquito larvae are inserted into glass tubes to be tamed in the laboratory.

Identification is only performed on adult Anopheles sp. Identification was carried out at the Laboratory Center of Entomology R \& D, Animal Source Control Disease (P2B2), Baturaja, South Sumatra. Identification keys are based on guidelines of illustration of Anopheles sp identification by [5]. 


\subsection{Data analysis}

The larvae calculation formula is as follows :

\section{The Index of Species Diversity}

The Shanon-Wiener [6] equation was used to calculate the index of larvae diversity.

$$
H^{\prime}=-\sum_{i}^{n} p i \operatorname{In} P i
$$

Where $: \mathrm{H}^{\prime}=$ Index of diversity species; $\mathrm{Pi}=\mathrm{ni} / \mathrm{N} ; \mathrm{ni}=$ Number of specific species; $\mathrm{N}=$ Total of individual species obtained

\section{Level of Species Density}

According to [7] the density of larvae is formulated as follows:

$$
\text { Density of Larva }=\frac{\text { number of larvae per species }}{\text { number of injuries }}
$$

\section{Determination of Population Distribution by Morisita Index}

As stated by [8] in the previous related study, Morisita Index was formulated :

$$
\frac{I d=n \sum_{i}^{n}={ }_{0} X i^{2}=N}{N(N-1)}
$$

Where:

$\mathrm{N} \quad=$ Total of the individual in the plot;

$\mathrm{n} \quad=$ Number of plots;

$\mathrm{Xi2}=$ Squared of a certain number of individuals on the plot to $\mathrm{i}$.

\section{Results And Discussion}

\subsection{Breeding habitat characteristics larva Anopheles sp.}

Abiotic environment factor plays an important role in the breeding of Anopheles sp larvae. Temperature affects the development of parasites in Anopheles sp [9]. The temperature of the water is an abiotic factor that has a great influence on the proliferation of Anopheles larvae [10],[11]. According to [11], environmental factors (biotic and abiotic) are very influential on larvae life, distribution of mosquitoes, and the balance of mosquito populations in nature. According to [2] the optimal temperature for mosquito larvae develops around $30-32^{\circ} \mathrm{C}$, and develops well at $28^{\circ} \mathrm{C}$ whereas according to [9] the optimum temperature range for mosquito breeding in both aquatic and adult phases is $20-30^{\circ} \mathrm{C}$.

The temperature of the observed habitat ranged from $28^{\circ} \mathrm{C}-31^{\circ} \mathrm{C}$. The environmental temperature of these waters is convenient for the larvae of Anopheles. Breeding habitats at the study site are generally exposed to direct sunlight. Research by [12] shows high-temperature 
exposure $\left(29-33^{\circ} \mathrm{C}\right)$, causing the Anopheles splarva to develop faster. High temperatures cause larvae nutrient sources to be available in abundant quantities. Sunlight is related to plants around because some types of mosquitoes take shelter under the moss. Photosynthesis affects the dissolved oxygen content (DO) in water. This condition indirectly affects the density of mosquito larvae at the breeding site.

[13] states that mosquito's response to sunlight is different, such as Anopheles sundaicus like shade, Anopheles Hyrcanus and Anopheles pinculatus prefer open spaces. Anopheles barbirostis lives in the shade and light. According to [14], the color of turbid water will inhibit the penetration of light and disrupt photosynthesis.

The level of turbidity in the pool of water at the sampling point varies from turbid to clear. The habitat of the Anopheles larvae is turbid with a soil base. Conditions like this are found in rice fields, and swamps areas with a degree of acidity are low. Measurement results show larvae habitat has a pH of 5-6. According to [15], the breeding habitat of Anopheles larvae has a $\mathrm{pH}$ of $6-8$. In the dry season, the $\mathrm{pH}$ value in the Anopheles sp habitat tends to increase to 6.8-8.6 [16]. This degree of acidity acts to regulate respiration and photosynthesis. The deeper the water, the lower the $\mathrm{pH}$ value to reduce the $\mathrm{CO}_{2}$ content.

The existence of plants and aquatic animals affects the density of Anopheles larvae. Aquatic plants such as mangroves, moss, algae and other plants can protect mosquito larvae from sunlight. Aquatic plants become a refuge from predators and induce larvae carried by water flow [17]. Aquatic plants that dominate in larvae habitat in each observation location are Limnocharis Flava, Ipomoea aquatic and Oryza sativa. [9] stated that aquatic plants function as a food source while acting as a shelter and become a place for mosquitoes to do gonotrophic cycles. Therefore, larvae cannot be exposed to direct sunlight. The denser the water plants in the habitat, the larvae production will also increase because of its function. However, the presence of natural predators in these environments causes reduced larvae and decreases mosquito populations. Some types of predators found at the observation site are Odonata larvae, Limnocharia Flava, Cladocera, Rana sp, Chironomus sp, Pila ampullacea, Trichogaster pectoralis, and Gerridae.

\subsection{Breeding habitat characteristics larva Anopheles sp.}

Diversity, density, and distribution of Anopheles sp in Kemelak Bindung Langit Village, Ogan Komering Ulu District, South Sumatra Province are shown in Table 1. The diversity of Anopheles sp in Kemelak Village is in a low category $(<1)$. Weather conditions that are not supportive at the time of the study are the rainy season, which is estimated to cause larvae to be carried away by water flow. According to [17] Rainfall in the breeding grounds of mosquito larvae causes water to overflow and stronger water flow. Heavy water flow will eliminate larvae and mosquitoes. Also, each type of mosquito has different abilities to survive, multiply, and have different sensitivity.

Larvae density in Kemelak Bindung Langit Village, Ogan Komering Ulu District, South Sumatra Province ranged from 0.1 to 1.1 . According to [11], larvae density becomes an indicator of conducive or non-conducive habitat for Anopheles sp. Water level and movement of water in the habitat can cause larvae to spread above the surface. This may cause low larvae density, while high larvae density has an increase in Anopheles population. An increase in the number of mosquito populations will increase the transmission of malaria in the region. The research of [18] shown uncertain weather conditions have a positive and negative impact on the survival of Anopheles larvae. Changes in temperature and rainfall can cause mosquitoes to lay eggs more often and vector populations. 


\subsection{Determination of Population Distribution}

Dissemination of Anopheles sp habitat almost evenly distributed throughout the place. This shows that all habitats are conducive to breeding Anopheles sp. The highest larvae density of 1.1 was found in rice field habitat. Larvae are dispersed in a variety of random, group and uniform. The results of the analysis using the morisita index show the distribution pattern of Anopheles larvae at the sampling location is uniform. This uniform distribution pattern is thought to be due to the similarity of environmental factors for each sampling location. Warm water temperature, sunlight intensity, and high air humidity in Kemelak Bindung Langit Village, Ogan Komering Ulu Regency, South Sumatra is an excellent environmental characteristic for living from Anopheles sp.

Table 1. Diversity, density, and distribution of Anopheles sp at Kemelak Bindung Village

\begin{tabular}{cllccc}
\hline Location & Habitat & Species of Anopheles & $\begin{array}{c}\text { Density } \\
\text { of } \\
\text { larvae }\end{array}$ & $\begin{array}{c}\text { Diversity of } \\
\text { Anopheles }\end{array}$ & $\begin{array}{c}\text { Distribution } \\
\text { of Anopheles } \\
\text { sp }\end{array}$ \\
\hline RT1 & Paddy field & An. vagus & 1.1 & 0.3387 & 0.95 \\
& & An. barbirostris & 0.5 & 0.3159 & 0.03 \\
& & An. vagus (male) & 0.4 & 0.3417 & 0.04 \\
RT1 & Puddle of vehicle & An. pediateniatus & 0.1 & 0.1450 & 0.19 \\
& wheels & An. vagus jantan & 0.2 & 0.3219 & 0.06 \\
& & An.vagus & & & 0.28 \\
RT2 & Paddy field & An. Vagyus(male) & 0.6 & 0.3065 & 0.06 \\
& Passy filed & An. vagus & 0.2 & 0.3219 & 0 \\
RT2 & Swamp & An. barbirostris & 0.6 & 0.3679 & 0.18 \\
& & An. vagus & 0.1 & 0.3306 & 0.90 \\
RT2 & Puddle of vehicle & An. barbirostris & 0.8 & 0.2703 & 0.36 \\
RT5 & Paddy field & - & 0.4 & 0.3662 & 1.57 \\
RT5 & Swamps & An. vagus & 0.2 & 0 & 0.12 \\
& & An. barbirostris & - & - & - \\
& & An. Vagus(male) & 0.1 & 0.2303 & 0.66 \\
RT5 & Duck pond & An vagus & 0.1 & 0 & 0.26 \\
RT6 & Paddy fied & An. barbirostris & 0.4 & 0.3679 & 0.90 \\
& & An. vagus & 0.6 & 0.3306 & 0.18 \\
& & An. barbumbrosus & 0.1 & 0.2180 & 0.36 \\
\hline
\end{tabular}

According to [8], mosquitoes have uniform distribution types. The difference in the value of larvae density is due to the presence of predators in their breeding habitat. The absence of aquatic fauna as natural enemies causes larvae to live freely without the threat of predation [19]. According to [20], if species diversity in a location shows moderate diversity, then the condition of the ecosystem at that location is a balanced and ecologically low pressure. The 
low larvae diversity obtained is thought to be influenced by several factors such as weather factors and the mosquito life cycle. Research of [21] states regeneration survival mosquitoes are influenced by biotic and abiotic factors that support their growth and development needs. Factors it is different in each region geographical so that it is specific local for each species in each region. Presence of waters in an area will affect the presence of mosquito populations. High larvae population density is one the area will determine its height mosquito population so it can affect the amount of frequency contact people and mosquitoes in the area

The study was conducted in the rainy season. Rain causes the fewer distribution of mosquitoes. According to [22] pre-adult Anopheles sp distribution in various habitats is related to the season. During the dry season, the breeding place will dry so that the mosquitoes will look for new breeding grounds. In these habitats, mosquito breeding sites will spread. In the rainy season the mosquito population increases, but for a long time causes the larvae to get carried away by the overflow of water.

Based on the survey results, it is known that the location of the discovery of Anopheles larvae is adjacent to the settlement. Breeding habitats close to human settlements cause people at risk of malaria. In this study, it is known that the distance between breeding habitats and residential areas is 5 to 30 meters. [23] explains the risk of malaria transmission depending on the distance of flying Anopheles sp. Mosquitoes have a limited flying distance, usually no more than 2-3 km from the place of their breeding habitat. According to [24], biological environments such as natural predators and cattle barriers affect the development of Anopheles vectors.

\section{Conclusion}

Based on the results obtained, it can be concluded that (1) abiotic environmental factors (temperature $28-31^{\circ} \mathrm{C}$; $\mathrm{pH} 5-6$, and humidity $60 \%-70 \%$ ) and biotic (water vegetation and the presence of natural predators) in the sampling location form suitable habitat for breeding of Anopheles larvae; (2) the distribution of larvae from Anopheles is categorized uniformly (the morisite index value is less than 1); (3) identification of pre-adult Anopheles obtained 4 species of Anopheles namely Anopheles vagus, Anopheles barbirostris, Anopheles barbumbrosus, and Anopheles pediateniatus; (4) the community is at high risk of contracting malaria due to the distance of residence adjacent to Anopheles habitat

\section{References}

[1] Sopi, B., P., I., I.: Some behavioral aspects of Anopheles sundaicus in Konda Maloba Village, South Katikutana District, Central Sumba Regency. Aspirator Journal. Vol. 6.pp. 63-72.(2014)

[2] Ni'mah, T., Nungki, H, S., \& Vivin, M.: Ecology of Anopheles Spp.Breeding Habitat in Simpang Empat Village, Lengkiti District, Ogan Komering Ulu, South Sumatra. Journal of Health Ecology vol.14.pp.342-349.(2015)

[3] South Sumatra Provincial Health Office.: South Sumatra Province Health Profile. Palembang.pp.6-9 (2014)

[4] Hakim, L.Malaria: Epidemiology and Diagnosis. Aspirator Journal.Vol.3.pp. 107-116. (2011)

[5] O'Connor \& Soepanto.: Key Picture of Adult Anopheles Mosquitoes in Indonesia. Jakarta: Ministry of Health of the Republic of Indonesia. Directorate General of Eradication of Communicable Diseases and Environmental Health.Vol.52.pp.69-77. (1999)

[6] Magurran, A.E.: Measuring Biological Diversity. New Jersey: Princeton University Press.pp.67-80. (2004) 
[7] Ministry of Health of the Republic of Indonesia.: Communicable and Environmental Health Prevention. Ecology Guidelines and Vector Behavior Aspects. Jakarta.pp.26-30.(2004)

[8] Gama, P, Z., Amin, S, L., \& Madaniatul, I.: Distribution and Composition of Mosquitoes in the Mojokerto Region. Biotropika Journal. Vol.1.pp.1-6. (2013)

[9] Taviv, Y., Anif, B., Hotnida, S, Lasbudi, P, A., Rika, M \& Pahlepi, I, R.: Distribution of Anopheles Mosquitoes in Different Topography in Jambi Province. Health Research and Development Media.Vol.25.pp.1-8. (2015)

[10] Rahman, R. R., Ishak., H \& Ibrahim, E.: Relation of Breeding Site Environmental Characteristics to Anopheles Larvae Density in Durikumba Health Center Work Area, Karossa Koh District. Central Mamuju. Makassar. Hasanuddin University.pp. 5-10.(2013)

[11] Kazwaini, M., \& Mading, M. Anopheles spp.: Ecology in Central Lombok Regency. Aspirator Journal Vol.6.pp.13-20.(2014)

[12] Pramestuti., N., Anggun., P., D \& Dyah., W.: Biotic and Abiotic Factors in Anopheles spp.Breeding Sites in Gunung Jati Village, Pagedongan District, Banjarnegara, Central Java Province. BALABA Journal Vol.13.pp.153-162.(2017)

[13] Arsin, A, A:Malaria in Indonesia : Aspect Review of Epidemiology. Makassar: Masagena Press. Pp. 67-08 (2012)

[14] Ibrahim., E., Ishak., H \& Rahman., R., R.: Correlation between Breeding Site Environmental Characteristics and Density of Anopheles Larvae in Durikumba Health Center Work Area, Karossa District, Central Mamuju District. Makassar: Hasanuddin University. Pp. 67-80.(2013)

[15] World Health Organization,.: Manual on Practical Entomology in Malaria Part I and II. Geneva.pp.23-40. (1975).

[16] Raharjo M, Sutikno S., J \& Mardihusodo. Regional Characteristics as Determinants of Anopheles aconitus Distribution in Jepara Regency. In the First Congress of Indonesia Mosquito Control Association in the Commemoration of Mosquito Day. Yogyakarta.pp.54-64.(2003)

[17] Pratama, Y.G.:Anopheles sp mosquitoes and influencing factors in Rajabasa sub-district, South Lampung. MAJORITY Journal. Vol.4.pp1-8.

[18] Mandasari, V.:Characteristics of Potential Habitat of Anopheles Mosquito Larvae and their Relationship with Malaria in Pangkal Pinang City, Bangka Belitung. Bogor: Bogor Agricultural University. Pp.45-50.(2012)

[19] Adnyana, N. W. D. Some Aspects of Bionomy Anopheles sp in Central Sumba Regency, East Nusa Tenggara Province. Health Research and Development Media Vol.21.pp. 62-70.(2011)

[20] Agus, M, Yulia Pujiastuti \& Yuanita Windusari. Diversity of the dragonfly (Odonata) as an indication of water quality. Science \& Technology Indonesia Vol.2.pp. 80-84.(2017)

[21] Adnyana, N. W. D \& Ruben W. Wila. Anopheles sp's Fauna In Southwest Sumba District. Journal of Health Ecology Vol 11.pp,211-219.(2011)

[22] Mardiana \& Perwitasari, D. 2010. Potential Habitat Of Anopheles vagus In Labuan And Sumur Sub-Districts In Pandeglang District In Banten Province. Journal of Health Ecology.Vol.9.pp.1139-1143

[23] Widjaja, J.Spatial Patterns of Malaria Cases in Santu'un Village, Muara Uya District, Tabalong Regency, South Kalimantan Province. Journal of Disease Vectors.Vol.4.pp.19-25. (2012)

[24] Gambiro, Hidayati \& Ginandjar, P.. Environmental factors related to the incidence of malaria (Study in the Work Area of Kepil I Community Health Center in Wonosobo District in 2004. Indonesian Journal of Environmental Health Vol.4.pp.1-8.(2005) 